\title{
The Carbon Dioxide System in the Ocean
}

\author{
by \\ Yasuo Miyake \\ Geochemistry Research Association, Tokyo \\ and \\ Katsuko Saruhashi \\ Meteorological Research Institute, Tokyo
}

(Received August 5, 1976)

\begin{abstract}
It is explained by the law of the ionic dissociation equilibrium that in the carbon dioxide system in sea water not only the bicarbonate ion content prevails among others $(>90 \%)$, but also it is nearly constant especially in deep layers $(94 \%)$. In the next place, in order to clarify the carbon dioxide system in the ocean, taking into consideration the effects of biological production and decay as well as dissolution and precipitation of calcium carbonate, the theoretical relations between the carbon dioxide system and biological processes are deduced. As to the ratio between calcium content and carbonate alkalinity, it is concluded from the theoretical view point that it is not constant but varies widely.

The discussion is done by using the observed date obtained during the Antipode 15 Expedition and others. The results show that there is a good agreement between observation and theory.
\end{abstract}

\section{Introduction}

It is well known that the carbon dioxide system in the ocean consisting of free carbonic acid $\left(\mathrm{H}_{2} \mathrm{CO}_{3}\right)$, bicarbonate ion $\left(\mathrm{HCO}_{3}^{-}\right)$ and carbonate ion $\left(\mathrm{CO}_{3}^{2-}\right)$ is mainly controlled by production and oxidative decomposition of organic matter, and formation and dissolution of solid carbonate represented by calcium carbonate. Among these processes, the relation between the total carbon dioxide content $\left(\Sigma \mathrm{CO}_{2}\right.$ or $\left.\mathrm{T}\right)$ and regeneration of carbon dioxide through oxidation of organic matter was discussed by the present authors many years ago (MIYAKE and SARUHASHI, 1956). They showed that the greater part of increase in the total carbon dioxide content as well as the alkalinity in the deep layers of the ocean is caused mainly by the oxidation of organic matter rather than the dissolution of calcium carbonate as previously suggested by MOBERG and REvelLe (1937) and other investigators.

In this paper, the carbon dioxide system in the ocean is studied in more detail taking the effect of dissolution of calcium carbonate on the carbonate alkalinity into consideration.

\section{The predominance and constancy of bicarbonate ion content in the carbon dioxide system in sea water}

According to the observations up to the present, in the carbon dioxide system in sea water, not only the relative amount of bicarbonate ion is very much higher than others, but also it is nearly constant especially in deep waters. In this section, the reasons 
for the predominance and constancy of the bicarbonate ion content in sea water are given.

There are the following well known equations concerning the electrolytic dissociation equilibrium of carbonic acid.

$$
\begin{aligned}
& \frac{\left[\mathrm{H}^{+}\right]\left[\mathrm{HCO}_{3}^{-}\right]}{\left[\mathrm{H}_{2} \mathrm{CO}_{3}\right]}=K_{1} \\
& \frac{\left[\mathrm{H}^{+}\right]\left[\mathrm{CO}_{3}^{2-}\right]}{\left[\mathrm{HCO}_{3}^{-}\right]}=K_{2}
\end{aligned}
$$

where $\left[\mathrm{H}^{+}\right],\left[\mathrm{H}_{2} \mathrm{CO}_{3}\right],\left[\mathrm{HCO}_{3}^{-}\right]$and $\left[\mathrm{CO}_{3}^{2-}\right]$ are the molar concentrations of respective chemical species, $K_{1}$ and $K_{2}$ are respectively the apparent first and second dissociation constant of carbonic acid. By combining the above two equations with the next equa. tion which defines the total carbon dioxide content,

$$
\mathrm{T}=\mathrm{F}+\mathrm{B}+\mathrm{C}
$$

where $\mathrm{F}=\left[\mathrm{H}_{2} \mathrm{CO}_{3}\right], \mathrm{B}=\left[\mathrm{HCO}_{3}^{-}\right]$and $\mathrm{C}=$ $\left[\mathrm{CO}_{3}^{2-}\right]$, the following three equations are deduced.

$$
\begin{aligned}
& \mathrm{F}=\frac{\mathrm{T} \cdot\left[\mathrm{H}^{+}\right]^{2}}{r} \\
& \mathrm{~B}=\frac{\mathrm{T} \cdot\left[\frac{\left.\mathrm{H}^{+}\right]}{r} \underline{K_{1}} .\right.}{\mathrm{C}}=\frac{\mathrm{T} \cdot K_{1} K_{2}}{\gamma},
\end{aligned}
$$

where

$$
\gamma=\left[\mathrm{H}^{+}\right]^{2}+\left[\mathrm{H}^{+}\right] K_{1}+K_{1} K_{2}
$$

In sea water, $\left[\mathrm{H}^{+}\right] K_{1}$ is much larger than both $\left[\mathrm{H}^{+}\right]^{2}$ and $K_{1} K_{2}$. For example, in sea water with a temperature of $10^{\circ} \mathrm{C}, \mathrm{pH}$ of 8.0 and a chlorinity of $19 \%$, the value of $\left[\mathrm{H}^{+}\right] K_{1}$ is $8.1 \times 10^{-15}$, while those of $\left[\mathrm{H}^{+}\right]^{2}$ and $K_{1} K_{2}$ are much lower, respectively $1 \times$ $10^{-16}$ and $4.1 \times 10^{-16}$. It may be said, therefore, that the main part of the total carbon dioxide content in sea water is bicarbonate ion. In other words, $\gamma$ is approximately equal to $\left[\mathrm{H}^{+}\right] K_{1}$. In fact, in the deep layers of the ocean where the temperature and $\mathrm{pH}$ are low and nearly constant, the percentage of bicarbonate ion in the total carbon dioxide content has a high and constant value of $94 \%$.

As regards the change in the fraction of each component $\mathrm{F}, \mathrm{B}$ and $\mathrm{C}$ in the total carbon dioxide content, a change of $K_{1}$ and $K_{2}$ with temperature, and a change of $\mathrm{pH}$ should be considered.

According to LyMAN (1957), by the change of temperature from $0^{\circ} \mathrm{C}$ to $20^{\circ} \mathrm{C}, K_{1}$ changes from $6.9 \times 10^{-7}$ to $9.3 \times 10^{-7}$, and $K_{2}$ changes from $3.8 \times 10^{-10}$ to $6.5 \times 10^{-10}$. On the other hand, when $\mathrm{pH}$ changes from 8.2 to 7.4 , the hydrogen ion concentration increases from $6.3 \times 10^{-9}$ mole/l to $4.0 \times 10^{-8}$ mole/1 which is seven times higher than the former. Therefore, it is evident that a change in $\mathrm{pH}$ is much more effective on the variation of the carbon dioxide system than a change in water temperature.

However, it is to be noted that the influences associated with a change of $\mathrm{pH}$ are mainly on the relative abundance of free carbonic acid and carbonate ion, while little effect is brought about on the fraction of bicarbonate ion.

The tendency of the fraction of free carbonic acid and carbonate ion contents to be controlled considerably by the hydrogen ion concentration is clearly shown by the approximate equation of Eqs. 4 and 6 as follows,

$$
\begin{aligned}
& \frac{\mathrm{F}}{\mathrm{T}} \div \frac{\left[\mathrm{H}^{+}\right]}{K_{1}} \\
& \mathrm{C} \div \frac{K_{2}}{\mathrm{~T}^{-} \div \frac{\left.\mathrm{H}^{+}\right]}{}}
\end{aligned}
$$

For example, in sea water with a chlorinity of $19 \%, \mathrm{~F} / \mathrm{T}$ and $\mathrm{C} / \mathrm{T}$ are respectively 0.009 and 0.09 at a temperature of $20^{\circ} \mathrm{C}$ and $\mathrm{pH}$ of 8.0 , while they change to 0.043 and 0.017 at $4^{\circ} \mathrm{C}$ and $\mathrm{pH} 7.5$. That is, under two different conditions $\mathrm{F} / \mathrm{T}$ increases by five times, while $\mathrm{C} / \mathrm{T}$ decreases to one fifth. On the contrary, $\mathrm{B} / \mathrm{T}$ changes only from 0.90 to 0.94 by the same change in sea water conditions.

\section{Two layer model of the carbon dioxide system in the ocean}

In the previous section, the predominance and constancy of bicarbonate ion content in sea water are explained from the theoretical 
view point. In this section, changes in the carbon dioxide system through biochemical processes are discussed in which production and oxidation of organic matter and dissolu. tion of calcium carbonate are involved.

The change in the total carbon dioxide content is expressed as follows:

$$
\mathrm{T}=\mathrm{T}_{0}+\Delta \mathrm{T}
$$

where

$$
\begin{aligned}
& \mathrm{T}_{0}=\mathrm{F}_{0}+\mathrm{B}_{0}+\mathrm{C}_{0} \\
& \Delta \mathrm{T}=\Delta \mathrm{F}+\Delta \mathrm{B}+\Delta \mathrm{C}
\end{aligned}
$$

where

$$
\begin{aligned}
& \Delta \mathrm{F}=\mathrm{F}-\mathrm{F}_{0}, \\
& \Delta \mathrm{B}=\mathrm{B}-\mathrm{B}_{0} \\
& \Delta \mathrm{C}=\mathrm{C}-\mathrm{C}_{0}
\end{aligned}
$$

By the definition $\Delta$ values in the above equations can be either positive or negative.

The ocean can be divided into two layers with respect to the carbon dioxide system, $i . e$. , the first layer from the surface to about $1,000 \mathrm{~m}$ depth, and the second layer from $1,000 \mathrm{~m}$ depth to the bottom. In the first layer, production and oxidative decomposition of organic matter and formation and dissolution of calcium carbonate take place actively. On the other hand, in the second layer, only regeneration of carbon dioxide from organic matter and redissolution of a small amount of calcium carbonate go on very slowly.

Concerning $T_{0}$ in Eqs. 10 and 11, it is defined that in the first layer, $T_{0}$ is the total carbon dioxide content which should be present originally when there are no biochemical reactions, and in the second layer, $\mathrm{T}_{0}$ is a part of the total carbon dioxide content which does not relate to the biochemical cycle. $\mathrm{F}_{0}, \mathrm{~B}_{0}$ and $\mathrm{C}_{0}$ are the components of $\mathrm{T}_{0} . \Delta \mathrm{T}$ is the amount of variation in the total carbon dioxide content, and $\Delta \mathrm{F}, \Delta \mathrm{B}$ and $\Delta \mathrm{C}$ are its components.

In the ocean, changes in the total carbon dioxide content are mainly caused by release or removal of free carbonic acid respectively through oxidation or production of organic matter, as well as by addition or deduction of carbonate ion respectively through dis- solution or formation of solid calcium carbonate.

The change in the total carbon dioxide content $(\mathrm{mM} / \mathrm{kg})$ through various biochemical processes in the first and the second layers can be expressed as follows.

$$
\begin{gathered}
\Delta \mathrm{T}_{1}=\Delta \mathrm{O}_{1}+\Delta \mathrm{D}_{1}^{\prime}-\Delta \mathrm{b}_{1} \\
\quad \text { (The first layer) } \\
\Delta \mathrm{T}_{2}=\Delta \mathrm{O}_{2}+\Delta \mathrm{D}_{2} \\
\quad \text { (The second layer) }
\end{gathered}
$$

The suffixes 1 and 2 represent respectively the first and the second layer. $\Delta \mathrm{O}$ is the amount of carbon dioxide released through oxidation of organic matter, $\Delta \mathrm{b}$ is the amount of carbon dioxide which is converted to organic matter through photosynthesis, $\Delta \mathrm{D}^{\prime}$ is the difference of the amounts of carbon dioxide released by the dissolution $(\Delta \mathrm{D})$, and lost by the formation of calcium carbonate. In the second layer, it is considered that the effects of formation of calcium carbonate and production of organic matter are negligible. No quantity in the above equations is constant, but varies with location and depth in each layer.

Among the above quantities, $\Delta \mathrm{O}$ is obtained by the apparent oxygen utilization (AOU), i.e., the difference of the saturated concentration of dissolved oxygen and the observed concentration in situ. It is assumed that $80 \%$ of $\mathrm{AOU}$ is used for oxidation of organic carbon. To estimate values of $\Delta \mathrm{D}$ and $\Delta \mathrm{D}^{\prime}$, a value of $[\mathrm{Ca}]_{0}$ must be known, which is the concentration of noncyclic calcium in the second layer with a total carbon dioxide of $T_{0}$. A probable value of $[\mathrm{Ca}]_{0}$ which is consistent with every other factor can be estimated by the method of trial and error to be described later.

In principle, $\Delta \mathrm{b}_{1}$ should be equal to the concentration of carbon in surface sea water remaining as organic compounds both in dissolved and particulate forms including living matter. However, a greater part of the organic carbon settles down to the deep as organic debris sooner or later after it has been produced in the surface layer. Therefore, the actual concentration of or- 
ganic carbon in the surface layer would be much smaller than $\Delta \mathrm{b}_{1}$. Judging from the vertical distribution of the organic carbon in the ocean, the organic carbon concentration remaining in the surface layer is approximately only a half of $\Delta \mathrm{b}_{1}$. At any rate, since $\Delta b_{1}$ can not be obtained directly from the observation, it must be calculated by using Eq. 16 as follows.

$$
\Delta \mathrm{b}_{1}=-\Delta \mathrm{T}_{1}+\Delta \mathrm{O}_{1}+\Delta \mathrm{D}_{1}^{\prime}
$$

However, in order to estimate the value of $\Delta \mathrm{b}_{1}, \Delta \mathrm{T}_{1}$ or $\mathrm{T}_{0}$ in the first layer must be known. It is assumed here that at the same station, $T_{0}$ has the same value both in the first and the second layer. In the second layer, $\mathrm{T}_{0}$ can be easily obtained by Eq. 17 .

Thus, the total carbon dioxide content in sea water in both layers can be written as follows.

$$
\begin{array}{r}
\mathrm{T}_{1}=\mathrm{T}_{0}+\Delta \mathrm{O}_{1}+\Delta \mathrm{D}_{1}^{\prime}-\Delta \mathrm{b}_{1} \\
\text { (The first layer) } \\
\mathrm{T}_{2}=\mathrm{T}_{0}+\Delta \mathrm{O}_{1}+\Delta \mathrm{D}_{2} \\
\text { (The second layer) }
\end{array}
$$

In the same way, using the relation

$$
\Delta \mathrm{B}=\Delta \mathrm{T}-(\Delta \mathrm{F}+\Delta \mathrm{C})
$$

the bicarbonate ion contents in the first and the second layer at the same station can be expressed as follows.

$$
\begin{array}{r}
\mathrm{B}_{1}=\mathrm{B}_{0}-\Delta \mathrm{F}_{1}-\Delta \mathrm{C}_{1}+\Delta \mathrm{O}_{1}+\Delta \mathrm{D}_{1}^{\prime}-\Delta \mathrm{b}_{1} \\
\text { (The first layer) } \\
\mathrm{B}_{2}=\mathrm{B}_{0}-\Delta \mathrm{F}_{2}-\Delta \mathrm{C}_{2}+\Delta \mathrm{O}_{2}+\Delta \mathrm{D}_{2} \\
\text { (The second layer) }
\end{array}
$$

As in the case of $T_{0}$, it is assumed that a value of $B_{0}$ is the same in both layers at the same station.

With respect to the carbonate alkalinity (CA, $\mathrm{m} \mathrm{eq} / \mathrm{kg}$ ), using the relation

$$
\Delta \mathrm{CA}=\Delta \mathrm{B}+2 \Delta \mathrm{C} \text {, }
$$

the following equations are deduced.

$$
\mathrm{CA}_{1}=\mathrm{CA}_{0}-\Delta \mathrm{F}_{1}+\Delta \mathrm{C}_{1}+\Delta \mathrm{O}_{1}+\Delta \mathrm{D}_{1}^{\prime}-\Delta \mathrm{b}_{1}
$$

(The first layer)

$$
\begin{aligned}
\mathrm{CA}_{2}=C \mathrm{~A}_{0}-\Delta \mathrm{F}_{2}+\Delta \mathrm{C}_{2}+\Delta \mathrm{O}_{2}+\Delta \mathrm{D}_{2} \\
\text { (The second layer) }
\end{aligned}
$$

It is also assumed here that a value of $\mathrm{CA}_{0}$ is the same in both layers at the same station.

\section{Relation between calcium content and carbonate alkalinity in sea water}

Up to now, many researchers (TSUNOGAI et al., 1973, Horibe et al., 1974, BREwer et al., 1975) have considered that the dissolution of $n$ mole of calcium carbonate in sea water should bring about the increase of $2 n$ equivalents in the carbonate alkalinity, because carbonate ion is divalent. From this view, they have tried to find out the $1: 2$ relationship between a change in calcium ion content (in mole) and that in the carbonate alkalinity (in equivalent) in sea water.

But this is not the case, because change in the carbonate alkalinity is controlled not only by the dissolution of carbonate, but also by other biochemical processes as shown in Eqs. 25 and 26. Since, as will be shown later, both the calcium content $[\mathrm{Ca}]$ and the carbonate alkalinity $\mathrm{CA}$ are smallest at the surface of the ocean, the ratio between each change in the two quantities can be obtained by taking a surface value of each component as a respective standard. Thus, the relation between changes of [Ca] and CA are derived from Eqs. 25 and 26 as follows, in which $\Delta \mathrm{D}^{\prime}$ or $\Delta \mathrm{D}$ is replaced by $\Delta[\mathrm{Ca}]$.

$$
\frac{\delta[\mathrm{Ca}]}{\delta \mathrm{CA}}=1--\beta \overline{\mathrm{C}}
$$

where

$$
\begin{gathered}
\delta[\mathrm{Ca}]=[\mathrm{Ca}]-[\mathrm{Ca}]_{\mathrm{s}} \\
\delta \mathrm{CA}=\mathrm{CA}-\mathrm{CA}_{\mathrm{s}} \\
\beta=-\left(\mathrm{F}-\mathrm{F}_{\mathrm{s}}\right)+\left(\mathrm{C}-\mathrm{C}_{\mathrm{s}}\right)+\left(\mathrm{O}-\mathrm{O}_{\mathrm{s}}\right)-\left(\Delta \mathrm{b}-\Delta \mathrm{b}_{\mathrm{s}}\right)
\end{gathered}
$$

and, $s$ denotes a surface value. It is assumed that $[\mathrm{Ca}]_{0}$ is the same in both layers at the same station.

The relation between calcium content and carbonate alkalinity is complicated and the ratio also changes widely as shown later in Table 4. 


\section{Discussion}

In order to prove the above views on the carbon dioxide system in the ocean, the total carbon dioxide content, the dissolved oxygen content, water temperature and salinity of sea water collected at the stations in the tropical area in the South Pacific Ocean covering the area of about $15^{\circ}-17^{\circ} \mathrm{S}$ and $170^{\circ}-173^{\circ} \mathrm{W}$ during the cruise of the Antipode 15 Expedition by the Scripps Institution of Oceanography and the observed values of the calcium content (HORIBE et al., 1974). Unfortunately, as $\mathrm{pH}$ values are not available in the above observations, those obtained in the nearby stations of the Southern Cross Expedition conducted by the Ocean Rezearch Institute of the University of Tokyo are used (HoriBE ed., 1970).

$\Delta \mathrm{b}_{1}$ is calculated by using Eq. 18. The results of calculation show that $\Delta \mathrm{b}_{1}$ is 140 $160 \mu \mathrm{M} / \mathrm{kg}$ which is about two times the surface concentration of organic carbon in the equatorial western Pacific (about 70-80 $\mu \mathrm{M} / \mathrm{kg}$ ). This ratio between $\Delta \mathrm{b}_{1}$ and the organic carbon concentration in the surface agrees very well with the above estimation given by the present authors. It is also reasonable to see that $\Delta \mathrm{b}_{1}$ tends to diminish with increasing depth, approaching zero at about $500 \mathrm{~m}$ below the surface which coincides with the depth of the bottom of euphotic zone.

The fraction of each component ( $F, B$ and $C$ ) is obtained from the observed values of the total carbon dioxide content $(\mathrm{T})$ by referring to the tables which were previously compiled by one of the present authors for different chlorinity, temperature and $\mathrm{pH}$ (SARUHASHI, 1955).

The carbonate alkalinity is obtained by using the calculated values of $\mathrm{B}$ and $\mathrm{C}$. The concentration of every chemical species is normalized to the salinity of $35 \%(\mathrm{Cl} ; 19.374$ $\%$ ). $[\mathrm{Ca}]_{0}$, the noncyclic calcium content in the second layer is determined to be $10.38 \mathrm{mM} / \mathrm{kg}$ by applying the trial and error method. In Figs. 1a to 1d are shown the
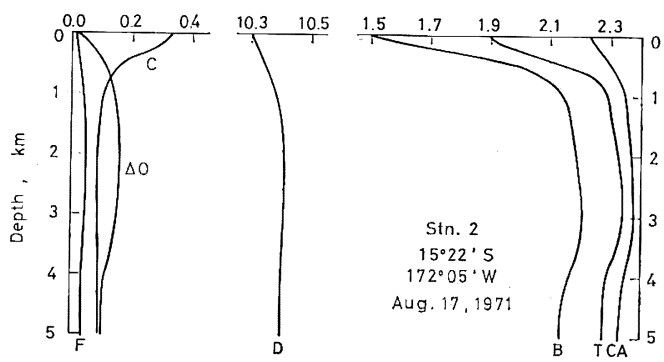

(a)
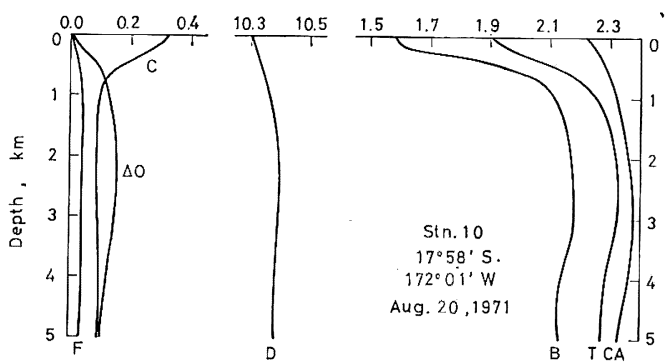

(c)
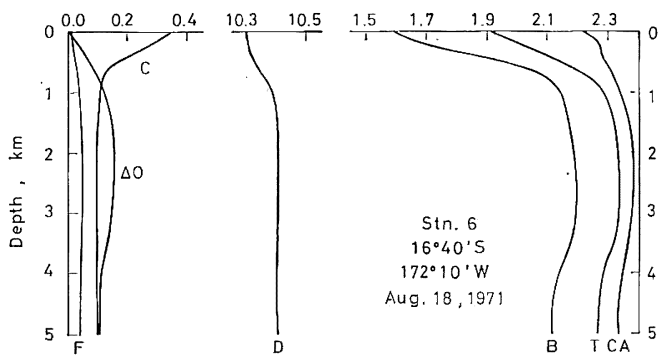

(b)
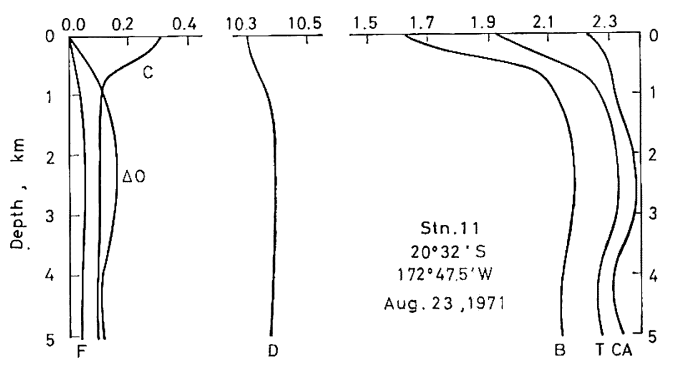

(d)

Fig. 1. Vertical distribution of components of carbon dioxide system.

Unit; $\mathrm{mM} / \mathrm{kg}$. CA, m eq/kg
a. Station 2
b. Station 6
c. Station 10
d. Station 11 
Table 1. Vertical distribution of $\Delta \mathrm{O}_{2}, \Delta \mathrm{D}_{2}, \mathrm{~B}_{0}$, $\mathrm{T}_{0}$ and $\mathrm{CA}_{0}$ in the second layer.

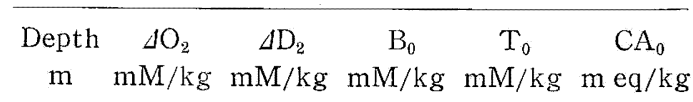

a. Station $2\left(15^{\circ} 22^{\prime} \mathrm{S}, 172^{\circ} 05^{\prime} \mathrm{W}\right)$

$\begin{array}{llllll}1,000 & 0.14 & 0.0 & 2.01 & 2.14 & 2.20 \\ 2,000 & 0.16 & 0.02 & 2.02 & 2.15 & 2.19 \\ 3,000 & 0.16 & 0.04 & 2.03 & 2.16 & 2.20 \\ 4,000 & 0.12 & 0.02 & 2.03 & 2.16 & 2.21 \\ 5,000 & 0.11 & 0.02 & 2.02 & 2.16 & 2.21\end{array}$

b. Station $6\left(16^{\circ} 40^{\prime} \mathrm{S}, 172^{\circ} 10^{\prime} \mathrm{W}\right)$

$\begin{array}{llllll}1,000 & 0.13 & 0.01 & 2.02 & 2.15 & 2.21 \\ 2,000 & 0.15 & 0.02 & 2.02 & 2.16 & 2.20 \\ 3,000 & 0.15 & 0.03 & 2.03 & 2.16 & 2.20 \\ 4,000 & 0.11 & 0.02 & 2.02 & 2.15 & 2.20 \\ 5,000 & 0.11 & 0.02 & 2.01 & 2.15 & 2.21\end{array}$

c. Station $10\left(17^{\circ} 58^{\prime} \mathrm{S}, 172^{\circ} 01^{\prime} \mathrm{W}\right)$

$\begin{array}{rrrrrr}1,000 & 0.14 & -0.02 & 2.01 & 2.15 & 2.20 \\ 2,000 & 0.16 & 0.02 & 2.02 & 2.15 & 2.20 \\ 3,000 & 0.16 & 0.02 & 2.03 & 2.16 & 2.21 \\ 4,000 & 0.12 & 0.01 & 2.03 & 2.16 & 2.21 \\ 5,000 & 0.11 & 0.01 & 2.02 & 2.16 & 2.21\end{array}$

d. Station $11\left(20^{\circ} 32^{\prime} \mathrm{S}, 172^{\circ} 47.5^{\prime} \mathrm{W}\right)$

\begin{tabular}{rrrrrr}
1,000 & 0.12 & -0.01 & 2.01 & 2.15 & 2.20 \\
2,000 & 0.16 & 0.02 & 2.01 & 2.15 & 2.20 \\
3,000 & 0.15 & 0.02 & 2.02 & 2.16 & 2.21 \\
4,000 & 0.11 & 0.01 & 2.02 & 2.15 & 2.20 \\
5,000 & 0.12 & 0.0 & 2.02 & 2.15 & 2.21 \\
\hline
\end{tabular}

vertical profiles of $\mathrm{T}, \mathrm{F}, \mathrm{B}, \mathrm{C}, \mathrm{CA}, \Delta \mathrm{O}$ and the calcium content from the surface to the bottom at Stns. 2, 6, 10 and 11 .

In Tables $1 \mathrm{a}$ to $1 \mathrm{~d}$, the calculated values by lising Eqs. 20, 23 and 26 of $\Delta \mathrm{O}, \Delta \mathrm{D}, \mathrm{B}_{0}$, $\mathrm{T}_{0}$ and $\mathrm{CA}_{0}$ in the second layer at the same stations as above are given.

In the upper part of Figs. $2 \mathrm{a}$ to $2 \mathrm{~d}$ are shown the vertical profiles in the second layer of $T_{2}, B_{2}$ etc. In the lower part, the calculated values of $\mathrm{T}_{0}, \mathrm{~B}_{0}$ and $\mathrm{CA}_{0}$ are shown. It is of interest that the values of $\mathrm{T}_{0}, \mathrm{~B}_{0}$ and $\mathrm{CA}_{0}$ are the same at the four station, i.e., $T_{0}$ is $2.15 \mathrm{mM} / \mathrm{kg}, B_{0}$ is 2.02 $\mathrm{mM} / \mathrm{kg}$ and $\mathrm{CA}_{0}$ is $2.20 \mathrm{~m} \mathrm{eq} / \mathrm{kg}$. By using these values $F_{0}$ and $C_{0}$ are obtained to be $0.04 \mathrm{mM} / \mathrm{kg}$ and $0.09 \mathrm{mM} / \mathrm{kg}$.

In Tables $2 \mathrm{a}$ to $2 \mathrm{~d}$ the calculated values of $\Delta \mathrm{O}_{1}, \Delta \mathrm{D}_{1}^{\prime}$ and $\Delta \mathrm{b}_{1}$ in the first layer are
Table 2. Vertical distribution of $\Delta \mathrm{O}_{1}, \Delta \mathrm{D}_{1}{ }^{\prime}$ and $\Delta \mathrm{b}$ in the first layer.

\begin{tabular}{cccc}
$\begin{array}{c}\text { Depth } \\
\mathrm{m}\end{array}$ & $\begin{array}{c}\Delta \mathrm{O}_{1} \\
\mathrm{mM} / \mathrm{kg}\end{array}$ & $\begin{array}{c}\Delta \mathrm{D}_{1}^{\prime} \\
\mathrm{mM} / \mathrm{kg}\end{array}$ & $\begin{array}{c}\Delta \mathrm{b}_{1} \\
\mathrm{mM} / \mathrm{kg}\end{array}$ \\
\hline a. Station & $2\left(15^{\circ} 22^{\prime} \mathrm{S}\right.$, & $\left.172^{\circ} 05^{\prime} \mathrm{W}\right)$ & \\
0 & 0.0 & -0.09 & 0.16 \\
100 & 0.01 & -0.09 & 0.16 \\
200 & 0.02 & -0.07 & 0.12 \\
300 & 0.05 & -0.06 & 0.09 \\
500 & 0.08 & -0.05 & 0.02 \\
750 & 0.13 & -0.03 & 0.0 \\
1000 & 0.14 & 0.0 & 0.0
\end{tabular}

b. Station $6\left(16^{\circ} 40^{\prime} \mathrm{S}, 172^{\circ} 10^{\prime} \mathrm{W}\right)$

$\begin{array}{rlrl}0 & 0.0 & -0.08 & 0.15 \\ 100 & 0.01 & -0.08 & 0.12 \\ 200 & 0.04 & -0.08 & 0.10 \\ 300 & 0.05 & -0.08 & 0.08 \\ 500 & 0.08 & -0.07 & 0.02 \\ 750 & 0.11 & -0.02 & 0.0 \\ 1000 & 0.13 & 0.01 & 0.0\end{array}$

c. Station $10\left(17^{\circ} 58^{\prime} \mathrm{S}, 172^{\circ} 01^{\prime} \mathrm{W}\right)$

$\begin{array}{rlll}0 & 0.0 & -0.07 & 0.16 \\ 100 & 0.01 & -0.07 & 0.16 \\ 200 & 0.04 & -0.07 & 0.15 \\ 300 & 0.05 & -0.07 & 0.09 \\ 500 & 0.06 & -0.05 & 0.02 \\ 750 & 0.10 & -0.03 & 0.0 \\ 1000 & 0.14 & -0.02 & 0.0\end{array}$

d. Station $11\left(20^{\circ} 32^{\prime} \mathrm{S}, 172^{\circ} 47.5^{\prime} \mathrm{W}\right)$

\begin{tabular}{rlll}
0 & 0.0 & -0.08 & 0.15 \\
100 & 0.02 & -0.08 & 0.13 \\
200 & 0.03 & -0.07 & 0.11 \\
300 & 0.05 & -0.06 & 0.08 \\
500 & 0.07 & -0.05 & 0.02 \\
750 & 0.10 & -0.03 & 0.0 \\
1000 & 0.12 & -0.01 & 0.0 \\
\hline
\end{tabular}

given at Stns. 2, 6, 10 and 11. In Tables 3a to $3 \mathrm{~d}$ the observed and the calculated values are compared with respect to $\mathrm{B}, \mathrm{T}$ and $\mathrm{CA}$ at the same stations. As described above it is assumed here that $\mathrm{T}_{0}$ etc., are the same in both the first and second layer at the same station.

In the upper part of Figs. 3a to $3 \mathrm{~d}$ the vertical profiles of $B_{1}, T_{1}, C_{1}$ etc., in the first layer at Stns. 2, 6, 10 and 11 are shown. In the lower part of Figs. 3a to 3d are given 

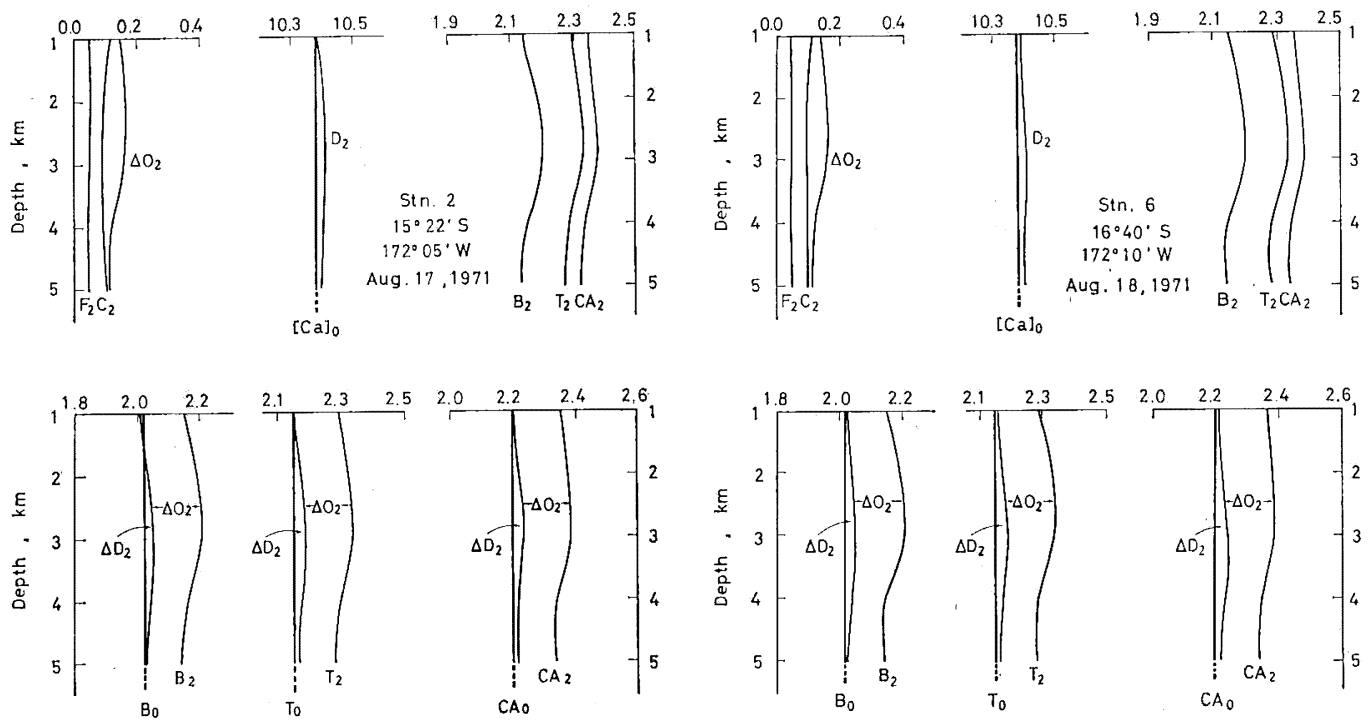

(a)

(b)
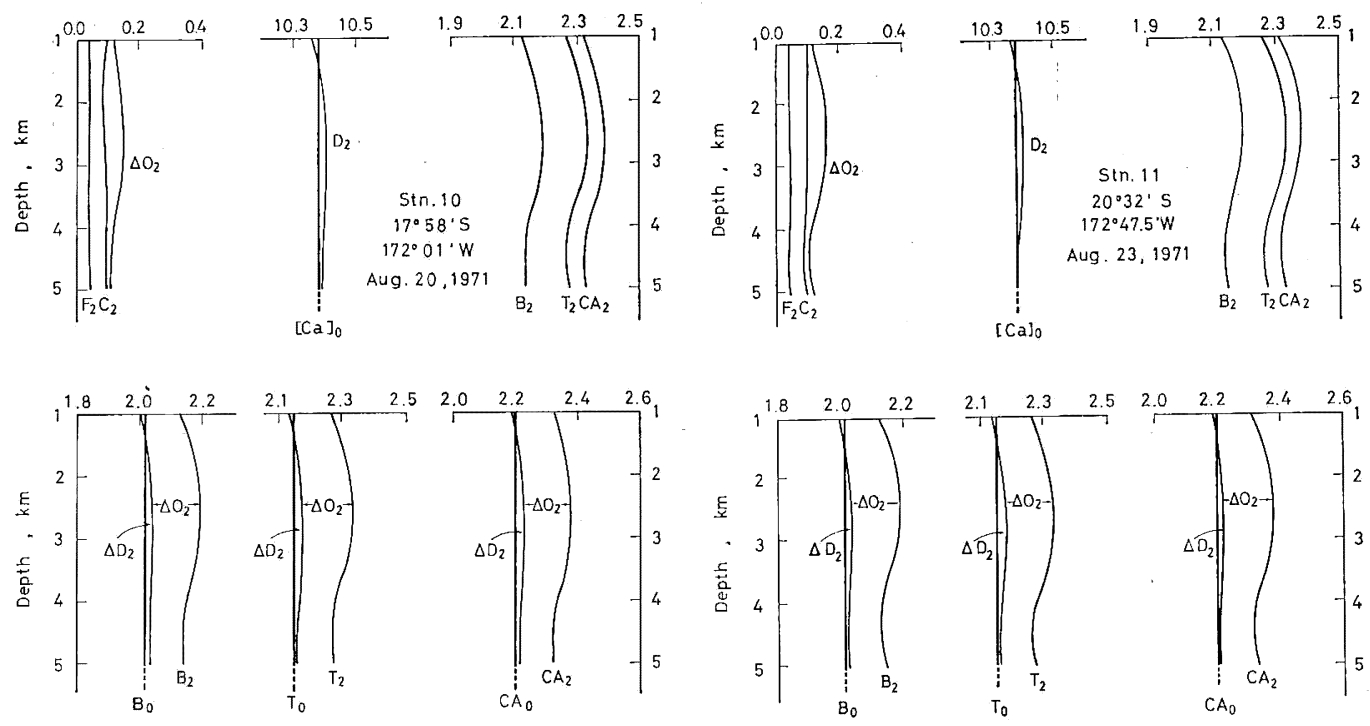

(c)

(d)

Fig. 2. Vertical distribution of components of carbon dioxide system in the second layer. Unit; $\mathrm{mM} / \mathrm{kg}$. CA, $\mathrm{m} \mathrm{eq} / \mathrm{kg}$
a. Station 2
b. Station 6
c. Station 10
d. Station 11 

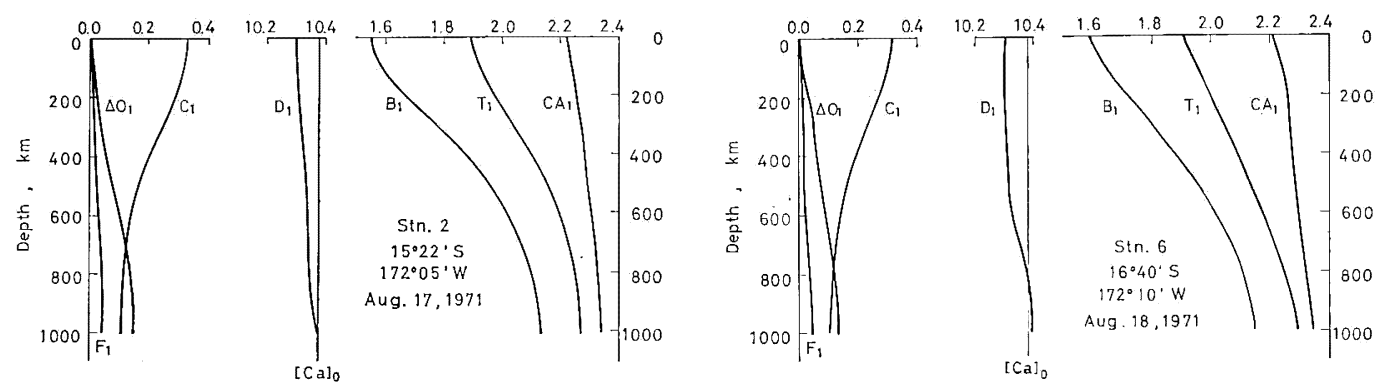

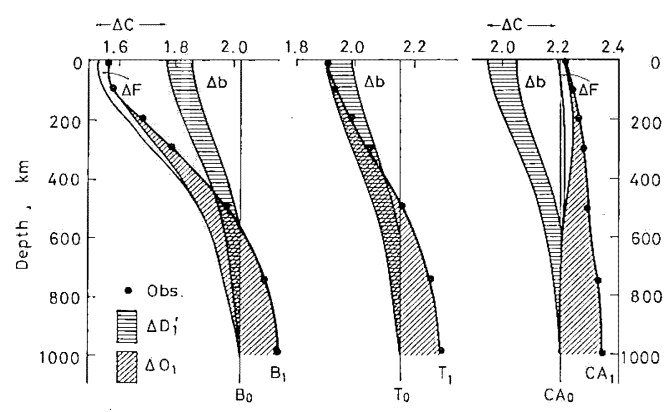

(a)
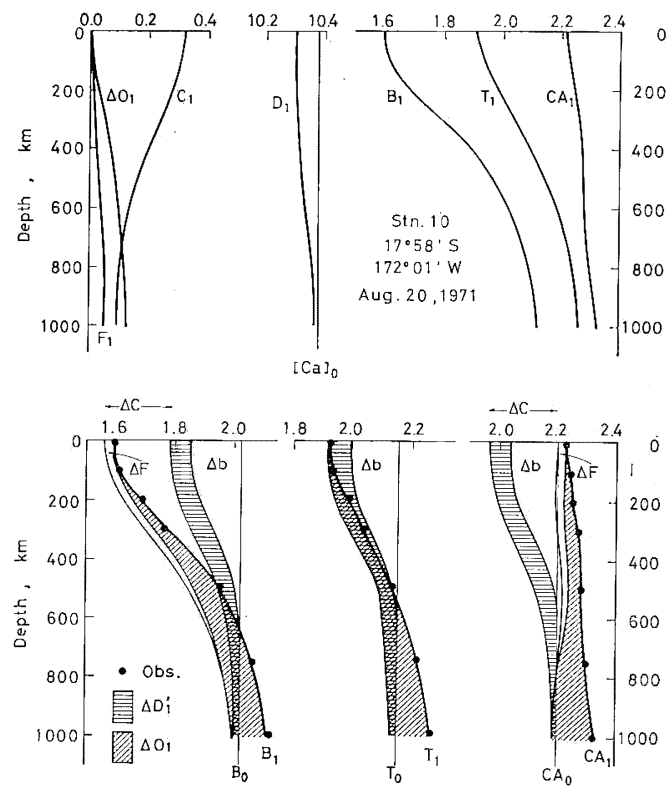

(c)

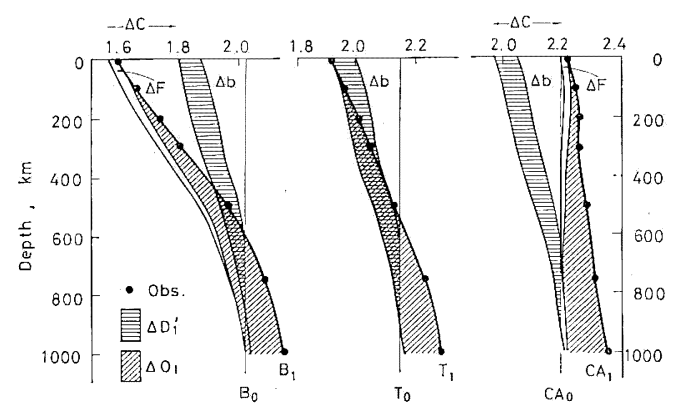

(b)
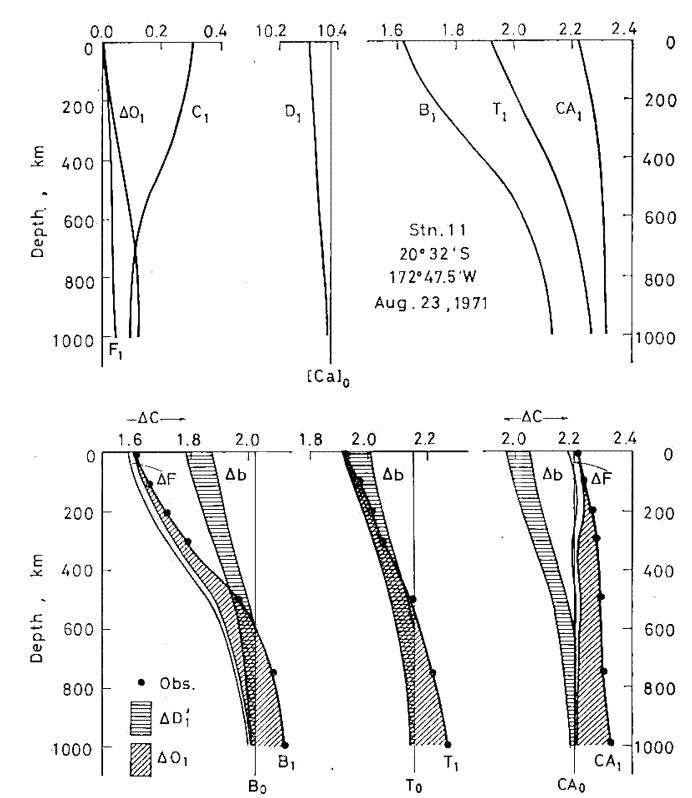

(d)

Fig. 3. Vertical distribution of components of carbon dioxide system in the first layer. Unit; $\mathrm{mM} / \mathrm{kg}$. CA, $\mathrm{m}$ eq $/ \mathrm{kg}$
a. Station 2
b. Station 6
c. Station 10
d. Station 11 
Table 3. Vertical distribution of $\mathrm{B}, \mathrm{T}$ and CA.

Depth B (mM/kg) T (mM/kg) CA (m eq/kg) $\mathrm{m}$ Calc. Obs. Calc. Obs. Calc. Obs.

a. Station $2\left(15^{\circ} 22^{\prime} \mathrm{S}, 172^{\circ} 05^{\prime} \mathrm{W}\right)$

$\begin{array}{rllllll}0 & 1.56 & 1.56 & 1.90 & 1.90 & 2.22 & 2.22 \\ 100 & 1.58 & 1.58 & 1.92 & 1.92 & 2.24 & 2.24 \\ 200 & 1.69 & 1.69 & 1.99 & 1.99 & 2.26 & 2.26 \\ 300 & 1.78 & 1.78 & 2.05 & 2.05 & 2.28 & 2.28 \\ 500 & 1.96 & 1.97 & 2.16 & 2.15 & 2.29 & 2.29 \\ 750 & 2.10 & 2.10 & 2.25 & 2.25 & 2.33 & 2.33 \\ 1,000 & 2.15 & 2.15 & 2.29 & 2.29 & 2.37 & 2.36 \\ 2,000 & 2.19 & 2.19 & 2.33 & 2.33 & 2.37 & 2.37 \\ 3,000 & 2.21 & 2.21 & 2.35 & 2.35 & 2.38 & 2.39 \\ 4,000 & 2.15 & 2.15 & 2.29 & 2.29 & 2.33 & 2.34 \\ 5,000 & 2.13 & 2.14 & 2.28 & 2.28 & 2.34 & 2.34\end{array}$

b. Station $6\left(16^{\circ} 40^{\prime} \mathrm{S}, 172^{\circ} 10^{\prime} \mathrm{W}\right)$

$\begin{array}{rllllll}0 & 1.59 & 1.59 & 1.92 & 1.92 & 2.22 & 2.22 \\ 100 & 1.65 & 1.65 & 1.96 & 1.96 & 2.25 & 2.25 \\ 200 & 1.73 & 1.73 & 2.01 & 2.01 & 2.27 & 2.27 \\ 300 & 1.79 & 1.80 & 2.04 & 2.05 & 2.26 & 2.26 \\ 500 & 1.96 & 1.96 & 2.14 & 2.14 & 2.29 & 2.29 \\ 750 & 2.09 & 2.09 & 2.24 & 2.24 & 2.32 & 2.32 \\ 1,000 & 2.16 & 2.15 & 2.29 & 2.29 & 2.34 & 2.35 \\ 2,000 & 2.19 & 2.19 & 2.32 & 2.33 & 2.37 & 2.37 \\ 3,000 & 2.20 & 2.20 & 2.33 & 2.34 & 2.38 & 2.38 \\ 4,000 & 2.15 & 2.14 & 2.28 & 2.28 & 2.33 & 2.34 \\ 5,000 & 2.15 & 2.14 & 2.28 & 2.28 & 2.33 & 2.34\end{array}$

c. Station $10\left(17^{\circ} 58^{\prime} \mathrm{S}, 172^{\circ} 01^{\prime} \mathrm{W}\right)$

$\begin{array}{rllllll}0 & 1.60 & 1.60 & 1.92 & 1.92 & 2.22 & 2.22 \\ 100 & 1.61 & 1.60 & 1.93 & 1.93 & 2.24 & 2.24 \\ 200 & 1.70 & 1.69 & 1.98 & 1.98 & 2.25 & 2.25 \\ 300 & 1.78 & 1.78 & 2.04 & 2.04 & 2.27 & 2.27 \\ 500 & 1.95 & 1.95 & 2.14 & 2.14 & 2.29 & 2.29 \\ 750 & 2.07 & 2.07 & 2.22 & 2.22 & 2.30 & 2.29 \\ , 000 & 2.12 & 2.12 & 2.27 & 2.27 & 2.32 & 2.32 \\ , 000 & 2.20 & 2.19 & 2.33 & 2.33 & 2.38 & 2.38 \\ , 000 & 2.20 & 2.20 & 2.33 & 2.33 & 2.38 & 2.39 \\ , 000 & 2.15 & 2.15 & 2.28 & 2.28 & 2.33 & 2.33 \\ 500 & 2.14 & 2.14 & 2.28 & 2.28 & 2.32 & 2.32\end{array}$

d. Station $11\left(20^{\circ} 32^{\prime} \mathrm{S}, 172^{\circ} 47.5^{\prime} \mathrm{W}\right)$

\begin{tabular}{rllllll}
0 & 1.61 & 1.62 & 1.92 & 1.92 & 2.21 & 2.22 \\
100 & 1.66 & 1.66 & 1.96 & 1.97 & 2.24 & 2.24 \\
200 & 1.73 & 1.72 & 2.01 & 2.01 & 2.26 & 2.26 \\
300 & 1.79 & 1.79 & 2.05 & 2.05 & 2.28 & 2.28 \\
500 & 1.97 & 1.97 & 2.15 & 2.15 & 2.29 & 2.29 \\
750 & 2.08 & 2.09 & 2.22 & 2.22 & 2.30 & 2.31 \\
1,000 & 2.13 & 2.13 & 2.26 & 2.26 & 2.31 & 2.31 \\
2,000 & 2.19 & 2.19 & 2.32 & 2.32 & 2.37 & 2.37 \\
3,000 & 2.19 & 2.19 & 2.32 & 2.33 & 2.37 & 2.37 \\
4,000 & 2.14 & 2.14 & 2.27 & 2.27 & 2.32 & 2.32 \\
5,000 & 2.14 & 2.15 & 2.27 & 2.28 & 2.32 & 2.33 \\
\hline
\end{tabular}

Table 4. The ratio of $\delta[\mathrm{Ca}]$ and $\delta[\mathrm{CA}]$.

\begin{tabular}{ccc}
$\begin{array}{c}\text { Depth } \\
\mathrm{m}\end{array}$ & Calc. & Obs. \\
\hline a. Station 2 & $\left(15^{\circ} 22^{\prime} \mathrm{S}, 172^{\circ} 05^{\prime} \mathrm{W}\right)$ \\
300 & 0.3 & 0.5 \\
500 & 0.7 & 0.6 \\
750 & 0.7 & 0.6 \\
1,000 & 0.7 & 0.6 \\
2,000 & 0.7 & 0.7 \\
3,000 & 0.7 & 0.8 \\
4,000 & 0.9 & 1.0 \\
5,000 & 0.9 & 0.9
\end{tabular}

b. Station $6\left(16^{\circ} 40^{\prime} \mathrm{S}, 172^{\circ} 10^{\prime} \mathrm{W}\right)$

$\begin{array}{rll}300 & 0.4 & 0.1 \\ 500 & 0.3 & 0.2 \\ 750 & 0.7 & 0.6 \\ 1,000 & 0.8 & 0.7 \\ 2,000 & 0.7 & 0.7 \\ 3,000 & 0.8 & 0.7 \\ 4,000 & 0.9 & 0.9 \\ 5,000 & 0.9 & 0.9\end{array}$

c. Station $10\left(17^{\circ} 58^{\prime} \mathrm{S}, 172^{\circ} 01^{\prime} \mathrm{W}\right)$

$\begin{array}{rll}300 & 0.1 & 0.1 \\ 500 & 0.3 & 0.3 \\ 750 & 0.6 & 0.6 \\ 1,000 & 0.5 & 0.6 \\ 2,000 & 0.6 & 0.6 \\ 3,000 & 0.6 & 0.5 \\ 4,000 & 0.8 & 0.7 \\ 5,000 & 0.8 & 0.8\end{array}$

d. Station $11\left(20^{\circ} 32^{\prime} \mathrm{S}, 172^{\circ} 47.5^{\prime} \mathrm{W}\right)$

$\begin{array}{rll}300 & 0.4 & 0.3 \\ 500 & 0.3 & 0.4 \\ 750 & 0.6 & 0.6 \\ 1,000 & 0.7 & 0.7 \\ 2,000 & 0.6 & 0.6 \\ 3,000 & 0.6 & 0.6 \\ 4,000 & 0.8 & 0.9 \\ 5,000 & 0.7 & 0.7\end{array}$

the schematical representations of Eqs. 19, 22 and 25 which are used for calculation of $B_{1}, T_{1}$ and $C A_{1}$. In these figures the calculated values of $B_{1}, T_{1}$ and $C_{1}$ are represented by thick lines and the observed values by solid circles. Tables $3 \mathrm{a}$ to $3 \mathrm{~d}$ and Figs. $3 \mathrm{a}$ to $3 \mathrm{~d}$ show a good agreement between calculation and observation of $B_{1}, T_{1}$ and $\mathrm{CA}_{1}$. 
In Table 4 are shown the observed and calculated values of the ratio of change with depth in the calcium content $\delta[\mathrm{Ca}]$ in mole and that in the carbonate alkalinity $\delta \mathrm{CA}$ in equivalent at Stns. 2, 6, 10 and 11. Calculated values are obtained by Eq. 28. As seen in Table 4 , there is a good agreement hetween the observed and calculated values of $\delta[\mathrm{Ca}] / \delta \mathrm{CA}$ showing that the ratio is not a constant value of 0.5 , but varies widely ranging from 0.1 to 1.0 .

These agreements suggest that the above consideration by the present authors on the carbon dioxide system in the ocean is right and appropriate. However, since the above discussions are mainly based on observations carried out in the tropical areas in the western part of the South Pacific, further studies in other areas in the world oceans are necessary.

Acknowledgements:-The authors with to express their thanks to Dr. Y. HoRIBE and his colleagues in the Ocean Research Institute of the University of Tokyo, and the staff members of the Scripps Institution of Oceanography who participated in the Antipode 15 Expedition, for providing the accurate and reliable data concerning the carbon dioxide system in the ocean.

\section{References}

Brewer, P. G., G. T. F. Wong, M.P. BACON and D. W. SPENCER, 1975: An oceanic calcium problem? Earth and Planetary Science Letters, 26, 81-87.

Horibe, Y., editor, 1970: Preliminary report of the Hakuho Maru Cruise KH-68-4, November, 1968-3 March, 1969, Central and South Pacific, $170 \mathrm{pp}$.

Horibe, Y., K. Endo and H. Tsubota, 1974: Calcium in the South Pacific and its correlation with carbonate alkalinity. Earth and Planetary Science Letters, 23, 136-140.

LYMAN, J., 1957: Buffer mechanism of sea water. $\mathrm{Ph}$. D. thesis, UCLA, $196 \mathrm{pp}$.

Miyake, Y. and K. Saruhashi, 1956: On the vertical distribution of the dissolved oxygen in the ocean. Deep-Sea Res., 3, 242-247.

Moberg, E. G. and R.R.D. Revelle, 1937: The distribution of dissolved calcium in the North Pacific. Internat. Assn. Phys. Oceanogr. (Union Geod. et Geophys. Internat., Assn. d'Oceanogr. Phys.), Process-verb., no. 2, p. 153.

SARuHAshi, K., 1955: On the equilibrium concentration ratio of carbonic acid substances dissolved in natural water. A study on the metabolism in natural waters II. Pap. Met. Geophys., 6, 38-55.

Tsunogai, S., H. Yamahata, S. Kudo and O. Saito, 1973: Calcium in the Pacific Ocean. Deep-Sea Res., 20, 717-726.

\section{海洋における二酸化炭素系について}

\section{三宅泰雄猿橋勝子 \\ （地球化学研究協会）（気象研究所）}

海洋中の二酸化炭素系は，イオンの解離平衡の法則に上れば，重炭酸イオンが最も多く存在し，全炭酸の $90 \%$ 以 上をしめる。重炭酸の含量は高いのみならず，特に深海においては，94\%の一定值をしめす。この理由から，少量 の炭酸イオン，ぬたは遊離炭酸が加えられた時には，これらの大部分は直ちに，重炭酸イオンに転換する。

次に, 全炭酸量 $(\mathrm{T})$, 重炭酸イオン含量 $(\mathrm{B})$ 招よび炭酸アルカリ度 $(\mathrm{C} A)$.を説明するために, 理論式をみち びいた。それは有機炭素の生産と分解，拉よび固体炭酸カルシウムの溶解と生成を考虑に入れたものである。また海

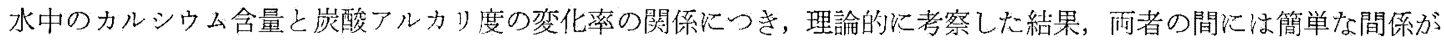
ないことを結論した。スクリップス海洋研究所が怙こった Antipode 15 Expedition の間に得られた生化学的過程 に関する測定值用いて，上記の $\mathrm{T}, \mathrm{B}, \mathrm{CA}$ 它定量的に求めた。計算の結果は，測定值と非常によい一致をしめ した。 